\title{
Gambaran Tingkat Pengetahuan dan Perilaku Masyarakat dalam Upaya Pencegahan Penularan COVID 19 di Wilayah Kerja Puskesmas III Denpasar Utara
}

\author{
Ni Putu Mia Devihapsari ${ }^{1}$, I Dewa Agung Sudarsana ${ }^{2}$, I Made Sudarma Adiputra ${ }^{3}$ \\ ${ }^{1}$ UPTD RS Nyitdah \\ ${ }^{2,3}$ STIKes Wira Medika \\ Email:devi.hapsari2015@gmail.com
}

Submitted : 07/05/2021

Accepted: 10/09/2021

Published: 15/09/2021

\begin{abstract}
COVID 19 is a new type of disease caused by SARS-CoV2 which attacks the respiratory system with a fast and aggressive spread. Human-to-human spread is the main source of transmission for COVID 19. Public knowledge about COVID 19 is important during this pandemic and affects the incidence and prevention behavior of COVID 19. This study aims to determine the level of knowledge and behavior of the community in efforts to prevent transmission. COVID 19. This research uses a quantitative descriptive design. The number of samples who participated in this study were 241 respondents, using simple random sampling technique. This research was conducted in Peguyangan Village from $01^{\text {st }}$ to $24^{\text {th }}$ December 2020. The research instrument used was an google form regarding knowledge and behavior. The results showed that respondents had good knowledge of COVID 19 (51.0\%), quite a lot (29.0\%) and less (19.1\%). Meanwhile, respondents who had good behavior to prevent COVID 19 were (88.0\%), sufficient behavior was (12.0\%) of respondents and had less behavior (0\%). Based on the results of the study, it can be concluded that respondents have good knowledge about COVID 19 and good behavior to prevent the transmission of COVID 19. The community is expected to work together and remain obedient in implementing COVID 19 prevention behavior to reduce the spread in the community.
\end{abstract}

Keywords: COVID 19, knowledge, preventive behavior

\begin{abstract}
Abstrak
COVID 19 adalah penyakit jenis baru yang disebabkan SARS-CoV2 yang menyerang sistem pernafasan dengan penyebaran sangat cepat dan agresif. Penyebaran dari manusia ke manusia menjadi sumber transmisi utama COVID 19. Pengetahuan masyarakat tentang COVID 19 merupakan hal yang penting dalam masa pandemi ini serta berpengaruh terhadap kejadian dan perilaku pencegahan COVID 19. Penelitian ini bertujuan mengetahui gambaran mengenai tingkat pengetahuan dan perilaku masyakarat dalam upaya pencegahan penularan COVID 19. Penelitian ini menggunakan desain deskriptif kuantitatif. Jumlah sampel yang berpartisipasi dalam penelitian ini adalah 241 responden, dengan teknik simple random sampling. Penelitian ini dilakukan di Kelurahan Peguyangan pada 01 sampai dengan 24 Desember 2020. Instrumen penelitian yang digunakan yaitu menggunakan google form mengenai pengetahuan dan perilaku. Hasil penelitian menunjukan bahwa reponden memiliki pengetahuan mengenai COVID 19 yang baik sebanyak (51,0\%), cukup sebanyak $(29,0 \%)$ dan kurang sebanyak $(19,1 \%)$. Sedangkan responden yang memiliki perilaku pencegahan COVID 19 yang baik sebanyak $(88,0 \%)$, perilaku cukup sebanyak $(12,0 \%)$ responden dan berperilaku kurang sebanyak $(0 \%)$. Berdasarkan dari hasil penelitian dapat disimpulkan bahwa responden memiliki pengetahuan mengenai COVID 19 yang baik dan perilaku pencegahan penularan COVID 19 yang baik pula. Masyarakat diharapkan dapat bekerja sama dan tetap patuh dalam menerapkan perilaku pencegahan COVID 19 untuk menekan penyebaran di masyarakat.
\end{abstract}

Kata Kunci : covid 19, pengetahuan, perilaku pencegahan covid 19 


\section{PENDAHULUAN}

Dunia di gemparkan oleh penyakit COVID 19 yang ditemukan pertama kali di Kota Wuhan Provinsi Hubei, China dan menyebar di lebih dari 190 negara (Susilo,dkk, 2020). Penyebaran virus yang cepat dan meluas di banyak negara yang menyebabkan peningkatan jumlah kasus positif serta angka kematian yang terus meningkat , pada tanggal 11 maret 2020 COVID 19 ditetapkan secara resmi sebagai pandemi oleh World Health Organization (WHO).

Severe Acute Respiratory Syndrome Coronavirus 2 (SARS-CoV2) atau COVID 19 merupakan corona virus jenis baru yang menyebar antar manusia (Kemenkes, 2020). Menurut Susilo ,dkk, (2020) pasien COVID 19 memiliki gambaran manifestasi klinis yang luas. Terdapat sekitar $80 \%$ kasus dalam kondisi ringan dan sedang, $13,8 \%$ kondisi sakit yang berat dan sebanyak $6,1 \%$ dalam kondisi yang kritis.

Menurut $\mathrm{Li}$ et al., (2020)Tingkat kematian pada kejadian SARS CoV dan MERS-CoV dilaporkan lebih dari $10 \%$ dan $35 \%$, sebagai perbandingan, COVID 19 memiliki tingkat kematian yang rendah. Namun, studi menemukan R0 pada COVID 19 sekitar 3,77 yang secara signifikan lebih tinggi dari MERS-CoV. R0 merupakan angka reproduksi atau potensi penularan dari penyakit COVID 19.

Berdasarkan data terbaru pada tanggal 9 September 2020 jumlah pasien yang terkonfirmasi positif di dunia sejumlah 27,7 juta orang, meninggal sebanyak 901.050 orang, dan terdapat 188 negara dengan kasus COVID 19. Data tersebut terus mengalami kenaikan karena adanya peningkatan kasus di berbagai negara. Adapun tiga negara dengan kasus COVID 19 terbanyak diantaranya Amerika Serikat 6.359.313 kasus, India 4.370.128 kasus dan Brazil 4.162.073 kasus (Hopkins University, 2020).

Data Kemenkes (2020) menyebutkan per tanggal 9 September 2020 saja jumlah kasus yang terkonfirmasi positif di Indonesia sebanyak 203.342 orang, meninggal 8.336 orang, jumlah sembuh 145.200 orang, dalam perawatan sebanyak 49.806 orang . Sejalan dengan data Kemenkes RI, Update data Dinas Kesehatan Provinsi Bali pada tanggal 9 september 2020 kasus yang terkonfirmasi positif sebanyak 6.723 orang, dalam perawatan 1.259 orang, sembuh 5.322 orang dan meninggal 142 orang. Adapun data persebaran kasus terkonfirmasi positif COVID 19 terbanyak ada pada Kota Denpasar 1.909 orang, Kabupaten Badung 958 orang dan terakhir diikuti oleh Kabupaten Gianyar sebanyak747 orang (P. K. Dinas, 2020).

Menurut data Dinas Kesehatan Kota Denpasar tahun 2020, data kasus di Kota Denpasar pada tanggal 9 september 2020 jumlah pasien yang terkonfirmasi positif 1.909 orang dari 43 desa atau kelurahan dan dari luar denpasar, jumlah pasien sembuh sebanyak 1.646 orang dan pasien meninggal sebanyak 30 orang. Adapun sepuluh kelurahan atau desa dengan kasus terbanyak pada tanggal 9 september 2020 Peguyangan masuk kedalam 10 kelurahan dengan kasus terbanyak yaitu 55 orang (Denpasar K. Dinas, 2020).

Menurut Susilo,dkk (2020) penyebaran dari manusia ke manusia menjadi penyebab utama transmisi sehingga penyebaran COVID 19 ini menjadi sangat agresif. Penularan melalui percikan droplet berisiko menginfeksi jika terkena mukosa konjungtiva, mukosa mulut maupun hidung (Nugroho ,dkk, 2020). Berdasarkan informasi dari World Health Organization (2020) sumber penularan COVID 19 seperti lingkungan terdekat dari orang yang terinfeksi dan seseorang yang berada dalam jarak relative pendek kurang dari 1 meter dengan orang yang mempunyai gejala pernafasan. Adanya penularan yang cepat menyebabkan meningkatnya kasus penyakit COVID 19 yang memberikan dampak merugikan bagi individu, 
masyarakat dan pemerintah. Mengingat COVID 19 merupakan penyakit baru yang kini sudah ditemukan vaksinnya, namun saat ini masih belum ditemukannya obat untuk mengobati virus ini sehingga diperlukan upaya pencegahan untuk mencegah penularan di masyarakat.

Upaya pencegahan yang dapat masyarakat lakukan secara mandiri diantaranya sering mencuci tangan dengan sabun, bekerja, menggunakan masker bila sakit atau saat ditempat umum, menjaga jarak dengan orang lain minimal 1 meter, menghindari kerumunan atau keramaian, segera mandi dan ganti pakaian setelah tiba dirumah, komsumsi gizi seimbang perbanyak sayur dan buah serta ke fasilitas kesehatan jika mengalami gejala pernafasan (Kemenkes, 2020).

Menurut

Purnamasari

(2020) pengetahuan tentang COVID 19 sangat diperlukan sebagai dasar masyarakat dalam menunjukan perilaku pencegahan. Menurut Donsu (2017) perilaku merupakan sebagian tindakan seseorang yang dapat diamati dan dipelajari. Faktor yang mempengaruhi perilaku adalah tingkat pengetahuan. Sejalan dengan penelitian yang dilakukan Ernawati N.\& Rahmawati F(2018) seseorang yang memiliki pengetahuan yang baik mengenai penyakit dan pencegahan cenderung memiliki perilaku pencegahan yang baik serta optimal.

Berdasarkan data Puskesmas III Denpasar Utara, Kelurahan Peguyangan merupakan daerah kasus COVID 19 paling tinggi di antara tiga Kelurahan atau Desa lainnya sebanyak 55 kasus. Studi pendahuluan yang dilakukan tanggal 10 september 2020 dengan memberikan kuisioner dan pengamatan oleh peneliti. Hasil studi pendahuluan yang dilakukan terkait dengan pencegahan yang dilakukan dimasyarakat, dari 10 masyarakat yang dipilih secara acak semua menjawab mengetahui pencegahan COVID 19. Namun, 6 orang diantaranya masih salah atau kurang dalam menyebutkan upaya pencegahan COVID 19 dan 4 orang sudah menjawab dengan benar.

Pengamatan yang peneliti lakukan masih terdapat masyarakat yang acuh terhadap penerapan protokol kesehatan seperti tidak menjaga jarak saat ditempat umum, penggunaan masker yang tidak benar atau melepas dan menurunkan masker jika berbicara, dan perilaku cuci tangan yang kurang. Padahal saat ini pemerintah terus melakukan promosi kesehatan baik melalui media massa, media sosial maupun media cetak tentang perilaku pencegahan penularan COVID 19. Melalui promosi kesehatan diharapkan peran serta masyarakat dalam memutus rantai penularan dari COVID 19.

Berdasarkan penjelasan diatas, penulis tertarik untuk meneliti " Gambaran tingkat pengetahuan dan perilaku masyarakat dalam upaya pencegahan penularan COVID 19 di wilayah kerja Puskesmas III Denpasar Utara “.

\section{METODE PENELITIAN}

Penelitian ini menggunakan desain deskriptif kuantitatif. Waktu pelaksanaan penelitian dilakukan pada 1 sampai dengan 24 Desember 2020. Populasi pada penelitian ini adalah masyarakat Kelurahan Peguyangan yang berada di Wilayah Kerja Puskesmas III Denpasar Utara sebanyak 11.066 orang yang tersebar di 13 banjar. Cara pengambilan sampel menggunakan probability sampling dengan teknik sampel yaitu simple random sampling. Sampel yang digunakan pada penelitian ini yaitu sebanyak 241 orang. Uji validitas dan reabilitas pada kuisioner ini sebelumnya sudah dilakukan dengan nilai $r$ hitung 0,187-1> r table 0,1409 dan Alpha Cronbach 0,770 (Emy, dkk, 2020).

Pengumpulan data pada penelitian ini menggunakan kuisioner online melalui google form dengan 10 pertanyaan pengetahuan. Pilihan jawaban benar skor 1 dan salah skor 0 pada pernyataan positif, jika pertanyaan negatif skor sebaliknya. 
Sedangkan perilaku yaitu 7 pertanyaan, jika pertanyaan positif memilih jawaban selalu skor 4 , hampir selalu skor 3 , jarang skor 2 dan tidak pernah 1. Untuk pertanyaan negatif skor sebaliknya. Analisa data yang digunakan pada penelitian yaitu analisis statistik deskriptif.

\section{HASIL DAN PEMBAHASAN}

Berdasarkan hasil penelitian yang dilakukan pada 241 orang di Kelurahan Peguyangan. Karakteristik responden yang diteliti diuraikan berdasarkan usia, jenis kelamin, pendidikan, pekerjaan dan pada variabel pengetahuan mengenai COVID 19 dan perilaku Pencegahan COVID 19 sebagai berikut :

Tabel 1. Distribusi Karakteristik Responden Berdasarkan Usia,

\begin{tabular}{ccc}
\hline $\begin{array}{c}\text { Usia } \\
\text { (tahun) }\end{array}$ & $\begin{array}{c}\text { Frekuensi } \\
\text { (f) }\end{array}$ & Persen (\%) \\
\hline & & \\
$15-25$ & 102 & $(42,3)$ \\
$26-35$ & 45 & $(18,7)$ \\
$36-45$ & 28 & $(11,6)$ \\
$46-55$ & 48 & $(19,9)$ \\
$56-64$ & 18 & $(7,5)$ \\
\hline
\end{tabular}

Berdasarkan tabel 1 diatas bahwa dari 241 responden didapatkan bahwa sebagian besar usia responden yang berpartisipasi adalah usia 15-25 tahun sebanyak $102(42,3 \%)$ responden.

Tabel 2. Distribusi Karakteristik Responden Berdasarkan Jenis kelamin

\begin{tabular}{ccc}
\hline $\begin{array}{c}\text { Jenis } \\
\text { Kelamin }\end{array}$ & $\begin{array}{c}\text { Frekuensi } \\
(\mathbf{f})\end{array}$ & $\begin{array}{c}\text { Persen } \\
(\boldsymbol{\%})\end{array}$ \\
\hline Laki-laki & 96 & $(5,9)$ \\
Perempuan & 145 & $(94,1)$ \\
\hline
\end{tabular}

Berdasarkan tabel 2 diatas bahwa dari 241 responden didapatkan bahwa sebagian besar responden berjenis kelamin perempuan dengan $154(94,1 \%)$ responden.
Tabel 3. Distribusi Karakteristik Responden Berdasarkan pendidikan

\begin{tabular}{lcc}
\hline Pendidikan & $\begin{array}{c}\text { Frekuensi } \\
\text { (f) }\end{array}$ & Persen (\%) \\
\hline SD & 17 & $(7,1)$ \\
SMP & 19 & $(7,9)$ \\
SMA & 99 & $(41,1)$ \\
Diploma & 28 & $(11,6)$ \\
Sarjana & 73 & $(30,3)$ \\
Magister & 5 & $(2,1)$ \\
\hline
\end{tabular}

Berdasarkan tabel 3 diatas dapat dijelaskan bahwa 241 responden yang dibedakan menurut karakteristik pendidikan didapatkan bahwa sebagian besar responden $99(41,1 \%)$ berpendidikan SMA.

Tabel 4. Distribusi Karakteristik Responden Berdasarkan pekerjaan

\begin{tabular}{lcc}
\hline Pekerjaan & $\begin{array}{l}\text { Frekuensi } \\
(\mathbf{f})\end{array}$ & $\begin{array}{l}\text { Persen } \\
(\mathbf{\%})\end{array}$ \\
\hline IRT & 35 & $14,5)$ \\
PNS & 12 & $(5,0)$ \\
Karyawan swasta & 73 & $(30,3)$ \\
Pelajar & 24 & $(10,0)$ \\
Wirausaha & 43 & $(17,8)$ \\
Tidak Bekerja & 18 & $(7,5)$ \\
Lainnya & 36 & $(14,9)$ \\
\hline
\end{tabular}

Berdasarkan tabel 4 diatas bahwa dari 241 responden didapatkan bahwa sebagian besar responden yaitu 73 (30, 3\%). bekerja sebagai karyawan Swasta.

Tabel 5. Proporsi Tingkat Pengetahuan mengenai COVID 19

\begin{tabular}{lcc}
\hline Kategori & $\begin{array}{c}\text { Frekuensi } \\
(\mathbf{f})\end{array}$ & $\begin{array}{c}\text { Persen } \\
(\boldsymbol{\%})\end{array}$ \\
\hline Baik & 123 & $(51,0)$ \\
Cukup & 72 & $(29,9)$ \\
Kurang & 46 & $(19,1)$ \\
\hline
\end{tabular}

Berdasarkan dari tabel 5 diatas dapat dijelaskan bahwa dari 241 responden dalam penelitian ini, sebagian besar responden termasuk dalam kategori pengetahuan yang baik mengenai COVID 19 sebanyak 123 $(51,0 \%)$. 
Tabel 6. Proporsi Perilaku Masyarakat dalam Upaya Pencegahan Penularan COVID 19

Perilaku

\section{Frekuensi}

(f)

\begin{tabular}{lcc}
\hline Baik & 123 & $(51,0)$ \\
Cukup & 72 & $(29,9)$ \\
Kurang & 46 & $(19,1)$ \\
\hline
\end{tabular}

\section{Persen}

$(\%)$

$(51,0 \%)$
Berdasarkan dari tabel 6 diatas dapat dijelaskan bahwa dari 241 responden dalam penelitian ini, sebagian besar responden termasuk dalam kategori pengetahuan yang baik mengenai COVID 19 sebanyak

Tabel 7. Frekuensi dan presentasi tingkat pengetahuan masyarakat mengenai COVID 19

\begin{tabular}{|c|c|c|c|c|}
\hline \multirow{3}{*}{ Pernyataan } & \multicolumn{4}{|c|}{ Pilihan Jawaban } \\
\hline & \multicolumn{2}{|c|}{ Benar } & \multicolumn{2}{|c|}{ Salah } \\
\hline & $f$ & $\%$ & $F$ & $\%$ \\
\hline $\begin{array}{l}\text { COVID-19 adalah penyakit yang tidak } \\
\text { berbahaya dan sama seperti flu biasa }\end{array}$ & 54 & $(22,4)$ & 187 & $(77,6)$ \\
\hline $\begin{array}{l}\text { Virus korona dapat bertahan hidup } \\
\text { beberapa jam di luar tubuh manusia }\end{array}$ & 170 & $(70,5)$ & 71 & $(29,5)$ \\
\hline $\begin{array}{l}\text { Virus korona tidak akan menular pada } \\
\text { saat berbicara }\end{array}$ & 52 & $(21,6)$ & 189 & $(78,4)$ \\
\hline $\begin{array}{l}\text { Orang yang bisa menularkan COVID- } \\
19 \text { hanyalah yang memiliki gejala }\end{array}$ & 86 & $(35,7)$ & 155 & $(64,3)$ \\
\hline $\begin{array}{l}\text { Orang yang sehat tidak perlu memakai } \\
\text { masker saat keluar rumah }\end{array}$ & 0 & 0 & 241 & (100) \\
\hline $\begin{array}{l}\text { Gejala COVID-19 pada usia lanjut } \\
\text { umumnya lebih berat dari pada pada } \\
\text { usia muda }\end{array}$ & 221 & $(91,7)$ & 20 & $(8,3)$ \\
\hline $\begin{array}{l}\text { Risiko kematian pasien COVID } 19 \text { lebih } \\
\text { tinggi pada penderita penyakit kronis }\end{array}$ & 199 & $(82,6)$ & 42 & $(17,4)$ \\
\hline $\begin{array}{l}\text { Anak-anak tidak termasuk kelompok } \\
\text { yang berisiko karena jarang terinfeksi } \\
\text { COVID- } 19\end{array}$ & 62 & $(25,7)$ & 179 & $(74,3)$ \\
\hline $\begin{array}{l}\text { New normal artinya adalah kembali } \\
\text { kepada kebiasaan semula sebelum } \\
\text { munculnya wabah korona }\end{array}$ & 96 & $(39,8)$ & 145 & $(60,2)$ \\
\hline $\begin{array}{l}\text { Isolasi mandiri pada orang yang } \\
\text { terinfeksi COVID } 19 \text { tidak diperlukan } \\
\text { bagi yang tidak memiliki gejala }\end{array}$ & 67 & $(27,8)$ & 174 & $(72,2)$ \\
\hline
\end{tabular}


Tabel 8. Frekuensi dan presentasi perilaku masyarakat mengenai COVID 19 di Kelurahan Peguyangan tahun 2020

\begin{tabular}{|c|c|c|c|c|c|c|c|c|}
\hline \multirow{3}{*}{ Pernyataan } & \multicolumn{8}{|c|}{ Pilihan Jawaban } \\
\hline & \multicolumn{2}{|c|}{ Selalu } & \multicolumn{2}{|c|}{ Hampir selalu } & \multicolumn{2}{|c|}{ Jarang } & \multicolumn{2}{|c|}{ Tidak Pernah } \\
\hline & $f$ & $\%$ & $f$ & $\%$ & $F$ & $\%$ & $f$ & $\%$ \\
\hline 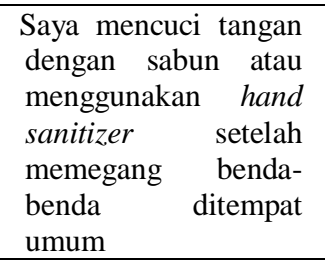 & 241 & $(100)$ & 0 & $(0)$ & 0 & $(0)$ & 0 & (0) \\
\hline $\begin{array}{l}\text { Saya mandi dan } \\
\text { mengganti pakaian } \\
\text { setelah pulang dari } \\
\text { berpergian }\end{array}$ & 240 & $(99,6)$ & 1 & $(0,4)$ & 0 & $(0)$ & 0 & (0) \\
\hline $\begin{array}{l}\text { Saya menggunakan } \\
\text { masker bila berada di } \\
\text { tempat umum (pasar, } \\
\text { terminal, tempat } \\
\text { sembahyang, dll) }\end{array}$ & 231 & $(95,9)$ & 7 & $(2,9)$ & 3 & $(1,2)$ & 0 & (0) \\
\hline $\begin{array}{l}\text { Saya menjaga jarak } \\
\text { minimal } 1 \text { meter dari } \\
\text { orang lain saat berada } \\
\text { di luar rumah }\end{array}$ & 164 & $(68,0)$ & 53 & $(22,0)$ & 20 & $(8,3)$ & 4 & $(1,7)$ \\
\hline $\begin{array}{ll}\text { Saya menjaga } & \text { jarak } \\
\text { dengan orang } & \text { yang } \\
\text { berusia lanjut } & \\
\end{array}$ & 106 & $(44,0)$ & 67 & $(27,6)$ & 55 & $(22,8)$ & 13 & $(5,4)$ \\
\hline $\begin{array}{l}\text { Saya menghadiri } \\
\text { acara yang } \\
\text { mengumpulkan } \\
\text { banyak orang } \\
\end{array}$ & 33 & $(13,7)$ & 20 & $(8,3)$ & 136 & $(56,4)$ & 52 & $(21,6)$ \\
\hline $\begin{array}{l}\text { Saya menggunakan } \\
\text { fasilitas umum atau } \\
\text { pergi ke tempat umum } \\
\text { (transportasi umum, } \\
\text { mall, pasar, tempat } \\
\text { wisata) }\end{array}$ & 28 & $(11,6)$ & 12 & $(5,0)$ & 110 & $(45,6)$ & 91 & $(37,8)$ \\
\hline
\end{tabular}

\section{Pengetahuan mengenai COVID 19}

Berdasarkan dari hasil penelitian mengenai pengetahuan COVID 19 yang dilakukan pada 241 responden sebagian besar responden dalam kategori pengetahuan yang baik sebanyak 123 $(51,0 \%)$ responden, cukup sebanyak 72 $(29,9 \%)$ responden dan kurang sebanyak 46 $(19,1 \%)$ responden.

Pada penelitian lain mengenai pengetahuan, sikap serta keterampilan mengenai pencegahan COVID 19 yang dilakukan di Provinsi Jakarta terdapat 83\% responden memiliki pengetahuan baik tentang bagaimana proses dari penularan penyakit, informasi terkait pencegahan COVID 19, dan informasi dari sebaran kasus (Utami et al., 2020).
Sejalan penelitian yang dilakukan (Purnamasari, 2020) menyebutkan bahwa 90,3\% masyarakat di Kabupaten Wonosobo menunjukan pengetahuan yang tinggi. Pengetahuan mengenai COVID 19 adalah hal penting pada masa pandemi ini serta berpengaruh terhadap kejadian dan pencegahan COVID 19, sehingga jika pengetahuan masyarakat baik mengenai pencegahan transmisi COVID 19, maka masyarakat dapat menentukan dan mengambil keputusan bagaimana ia harus menghadapinya.

Menurut Notoatmodjo (dalam Wawan A. dan M. Dewi, 2019) domain penting dalam terbentuknya tindakan seseorang (open behavior) adalah pengetahuan atau kognitif. Perilaku seseorang yang didasari 
oleh pengetahuan akan lebih langgeng daripada perilaku tanpa didasari oleh pengetahuan.

Bila dijabarkan satu persatu dengan pertanyaan yang diberikan kepada responden dapat dilihat bahwa ada sebesar $77,6 \%$ memilih pilihan salah dan 22,4\% memilih pilihan benar untuk pernyataan COVID-19 adalah penyakit yang tidak berbahaya dan sama seperti flu biasa. Faktanya, sekitar 80\% kasus COVID 19 tergolong ringan atau sedang (Susilo et al., 2020). COVID 19 menyebar dengan cepat dari manusia ke manusia sehingga penyebaran yang sangat mudah dan cepat, sehingga transmisi virus yg cepat ini menghasilkan suatu klaster penyakit dengan hanya kontak dengan pasien terinfeksi COVID 19.

Pada pernyataan mengensi virus masih dapat bertahan hidup beberapa jam di luar tubuh manusia,pada pernyataan tersebut terdapat $70,5 \%$ menjawab pilihan benar dan 29,5\% memilih salah. Sebuah penelitian menunjukan bahwa COVID 19 dapat ditemukan bertahan dalam aerosol selama kurang lebih 3 jam dan virus ini juga daoat ditemukan pada permukaan yang kering sekitar 8 hingga 72 jam tergantung dari jenis permukaan tersebut, Aytoğan et al., (2020). Sejalan dengan penelitian yang dilakukan oleh Fiorillo et al., (2020) menunjukan bahwa virus COVID 19 dapat tetap hidup dan menetap hingga 9 hari di suhu ruangan.

Sebagian besar responden memilih jawaban salah bahwa saat berbicara virus tidak akan menular. Faktanya transmisi virus ini dapat terjadi melalui kontak langsung, kontak tidak langsung maupun kontak erat dengan orang yang terinfeksi melalui droplet saluran nafas seperti batuk, bersin berbicara maupun menyanyi. Maka dari itu, dalam keadaan ini sangat penting menggunakan masker maupun menjaga jarak untuk mencegah penularan COVID 19 (World Health Organization, 2020b).
Pada pernyataan COVID-19 hanya menular pada orang yang memiliki gejala terdapat $64,3 \%$ responden memilih jawaban salah dan $35,7 \%$ responden memilih jawaban benar. Pasien COVID 19 tanpa gejala tetap berisiko menularkan ke orang yang sehat. Pasien yang tidak memiliki gejala juga memiliki hasil kultur virus positif yang menandakan pasien tersebut dapat menularkan COVID 19 (Arons et al., 2020).

Sebanyak $100 \%$ responden memilih jawaban salah untuk pernyataan orang sehat tidak perlu memakai masker. Panduan WHO (2020) menyebutkan masyarakat dianjurkan menggunakan masker sebagai bagian dari pendekatan yang menyeluruh untuk menekan penyebaran dari COVID 19. Faktanya penggunaan masker pada orang yang sehat dapat mencegah tertular maupun menulari orang lain.

Pada pernyataan usia lanjut umumnya memiliki gejala lebih berat dari pada usia muda, sebagian besar responden memilih jawaban benar 91,7\% dan jawaban salah 8,3\%. Kemungkinan pasien pada usia lanjut $>65$ tahun memiliki kemungkinan $5 \mathrm{x}$ lebih tinggi untuk dirawat dirumah sakit dan memiliki risiko kematian karena COVID 19 90x lebih tinggi dibandingkan usia dibawah 29 tahun (CDC, 2020).

Sebanyak 82,6 \% memilih jawaban benar pada pernyataan pasien COVID 19 yang menderita penyakit kronis memiliki risiko kematian yang lebih tinggi. Hal sejalan dengan penelitian yang dilakukan Satria et al.,(2020) menyebutkan penyakit komorbid seperti diabetes dan penyakit jantung menjadi faktor risiko kematian pada pasien COVID 19 .

Pada pernyataan bahwa anak-anak termasuk kelompok yang berisiko rendah karena jarang terinfeksi COVID 19 Terdapat 74,3\% menjawab salah dan $25,7 \%$ menjawab benar . Data dari China menunjukkan bahwa kasus COVID 19 pada anak mungkin tidak parah jika 
dibandingkan dengan kasus pada orang dewasa, bahkan anak-anak mungkin memiliki gejala yang berbeda dari orang dewasa. Dilaporkan sekitar 5,7\% - 20\% anak-anak dirawat di Rumah sakit dengan $(0,58 \%-2,0 \%)$ dirawat di (Bialek et al., 2020).

Terdapat sebanyak $27,8 \%$ responden menjawab pilihan salah pada pernyataan new normal adalah kembali kepada kebiasaan semula sebelum munculnya wabah korona. Lebih dari sebagian responden yaitu $72,2 \%$ menjawab benar. New normal dimasa pandemi yaitu adanya tatanan, kebiasaan maupun perilaku yang baru berbasis pada adaptasi untuk tetap menjalankan aktivitas seperti biasa namun selalu menerapkan protokol kesehatan ditengah pandemi

Pada pernyataan orang terinfeksi COVID 19 tanpa gejala tidak perlu isolasi mandiri sebanyak $27,8 \%$ memilih jawaban benar dan $72,2 \%$ memilih jawaban salah. Faktanya pasien yang tidak memiliki gejala juga memiliki hasil kultur virus positif yang menandakan pasien tersebut dapat menularkan COVID 19 (Arons et al., 2020). Pasien asimptomatik atau tidak bergejala merupakan aspek penting dan menjadi kontributor utama dalam penyebaran COVID 19. Selain usia yang lebih muda berkolerasi kuat dengan infeksi asimptomatik (Nikolai et al., 2020). Peneliti beropini edukasi yang diberikan terus menerus melalui media massa, media sosial, media cetak, maupun dari lingkungan masing-masing menyebabkan masyarakat memiliki pengetahuan yang baik mengenai COVID 19. Hal tersebut juga dipengaruhi oleh faktor-faktor lain seperti usia maupun pendidikan.

\section{Perilaku Mengenai Pencegahan Penularan COVID 19}

Berdasarkan hasil penelitian mengenai perilaku pencegahan penularan COVID 19 yang dilakukan pada 241 responden menunjukan bahwa $88 \%$ responden memiliki perilaku kategori baik, $12 \%$ memiliki perilaku cukup dan perilaku kurang sebanyak $0 \%$.

Sejalan dengan penelitian yang dilakukan di Kelurahan Baru Kotawaringin Barat, menunjukan $100 \%$ responden memiliki tingkat pengetahuan yang baik dan $23(46 \%)$ responden memiliki perilaku yang cukup baik tentang pencegahan COVID 19, hal tersebut menunjukan bahwa pengetahuan masyarakat yang semakin baik maka semakin baik pula tindakan masyarakat dalam pencegahan COVID 19.

Menurut . (Prihati et al., 2020) beberapa faktor seperti pengetahuan, persepsi, dan motivasi, keyakinan dalam upaya pengontrolan dan pencegahan penyakit, lingkungan dari pelayanan kesehatan maupun kemampuan masyarakat dalam mengakses sumber daya yang ada merupakan faktor yang mempengaruhi kepatuhan masyarakat dalam melakukan pencegahan COVID 19.

Bila dijabarkan satu persatu sebagian besar responden sudah menerapkan upaya pencegahan penularan COVID 19 seperti mencuci tangan menggunakan sabun atau Hand sanitizer, mandi dan mengganti pakaian setelah berpergian, menggunakan masker bila berada di tempat umum maupun diluar rumah dan menjaga jarak minimal 1 meter dari orang lain saat berada di luar rumah.

Terdapat $22,8 \%$ responden yang menjawab jarang dan 5,4\% menjawab tidak pernah menjaga jarak dengan orang lanjut usia. Berdasarkan dari wawancara dan pengamatan yang dilakukan, didapatkan bahwa sebagian kecil responden tinggal dengan orang lanjut usia dan seringnya berinteraksi dengan orang lanjut usia sehingga menyulitkan responden menjaga jarak dengan orang lanjut usia. Menurut data KPCPEN (2021) terdapat lansia >60 tahun terkonfirmasi positif yang meninggal dengan presentase $45 \%$ jika dilihat dari presentasenya kematian karena COVID 19 pada lansia ini tertinggi dibandingkan rentang usia lainnya. Penurunan daya tahan 
tubuh dan adanya penyakit komorbid pada lansia. menyebabkan lansia lebih rentan terinfeksi COVID 19.

Masih ditemukan $13,7 \%$ responden menjawab selalu dan $8,3 \%$ menjawab hampir selalu menghadiri acara yang mengumpulkan banyak orang. Tradisi masyarakat local (Local wisdom) yang merupakan kegiatan gotong royong dalam kebersamaan (menyamabraya) sangat nihil untuk tidak dilakukan, maka penerapan protocol kesehatan merupakan poin penting yang harus diingat dan diterapkan, sehingga pembagian kehadiran kegiatan sangat penting untuk dilakukan untuk mengurangi transmisi local dan kerumunan (Putra et al., 2020).

Terdapat $11,6 \%$ selalu dan 5\% hampir selalu responden yang menggunakan fasilitas umum atau pergi ke tempat umum seperti transportasi umum, mall, pasar maupun tempat wisata. Masih banyaknya tempat umum dan fasilitas umum yang belum mampu menerapkan adanya protokol kesehatan seperti menjaga jarak aman atau social distancing sehingga penularan COVID 19 menjadi sangat cepat dan mudah. Menurut Pujaningsih (2020) Pembatasan Kegiatan di Masyarakat atau PKM yang diterapkan oleh Pemerintah Kota Denpasar yang mana bertujuan menciptakan keteraturan dan ketertiban di masyarakat, namun masih ditemukannya masyarakat yang melanggar kebijakan tersebut. Adapun sanksi baik secara administratif maupun adat yang berlaku bagi pelanggar PKM tersebut. Sanksi yang dibuat bukan untuk menakuti masyarakat namun untuk meningkatkan kerjasama dan kesadaran masyarakat akan kedisiplinan disituasi pandemi ini. Hal tersebut sesuai dengan penegakan hukum protokol kesehatan sebagai upaya pencegahan dan pengendalian corona virus disease 2019 dalam tatanan kehidupan era baru yang termuat pada Peraturan dari Gubernur Bali No.6 tahun 2020.
Pengetahuan merupakan faktor yang mempengaruhi perilaku seseorang. Pengetahuan yang baik mengenai COVID 19 mendorong seseorang untuk berperilaku baik tentang pencegahan yang harus dilakukannya. Peneliti beropini adanya kewajiban yang harus dijalankan oleh masyarakat guna mengurangi penularan COVID 19 dan adanya unsur sanksi yang tegas dari pemerintah bagi yang melanggar protokol kesehatan membuat perilaku masyarakat mengenai pencegahan COVID 19 pada penelitian ini dalam kategori baik, walaupun presentase dari segi pengetahuan mengenai COVID 19 tidak setinggi dari presentase perilaku pencegahan.

\section{SIMPULAN}

Berdasarkan dari tujuan khusus penelitian ini, hasil penelitian menunjukan bahwa tingkat pengetahuan responden mengenai COVID 19 baik dan menunjukan perilaku pencegahan COVID 19 yang baik pula.

\section{SARAN}

Adapun saran yang dapat peneliti berikan yaitu diharapkan Perawat dan Puskesmas menambah materi mengenai informasi fakta seputar COVID 19 kepada masyarakat melalui media poster, sosial media maupun media lainnya untuk mencegah berita hoax yang beredar. Masyarakat diharapkan bekerja sama dan tetap patuh dalam menerapkan perilaku pencegahan COVID 19 untuk menekan penyebaran di masyarakat. Perlunya penelitian lebih lanjut mengenai faktorfaktor yang mempengaruhi perilaku dalam upaya pencegahan COVID 19 di masyarakat dan peneliti diharapkan pada penelitian selanjutnya melakukan observasi dimasyarakat mengenai pengetahuan dan perilaku pencegahan. Penelitian ini telah mendapatkan laik etik dari Poltekes Denpasar dengan Nomor: LB.02.03/EA/KEPK/01/2020 


\section{UCAPAN TERIMA KASIH}

Peneliti mengucapkan terima kasih kepada semua pihak yang sudah membantu dan terlibat di penelitian ini. Kepada Kepala Puskesmas III Denpasar Utara, Kepala Kelurahan Peguyangan, Kelian Dinas dan Adat serta seluruh masyarakat yang berpartisipasi dalam penelitia ini. Peneliti berharap penelitian ini menjadi rekomendasi penulis lain untuk membuat penelitian selanjutnya.

\section{DAFTAR PUSTAKA}

Arons, M. M., Hatfield, K. M., Reddy, S. C., Kimball, A., James, A., Jacobs, J. R., Taylor, J., Spicer, K., Bardossy, A. C., Oakley, L. P., Tanwar, S., Dyal, J. W., Harney, J., Chisty, Z., Bell, J. M., Methner, M., Paul, P., Carlson, C. M., McLaughlin, H. P., ... Jernigan, J. A. (2020). Presymptomatic SARS-CoV-2 Infections and Transmission in a Skilled Nursing Facility. New England Journal of Medicine, 382(22), 20812090.

https://doi.org/10.1056/nejmoa200845 7

Aytoğan, H., Ayintap, E., \& Özkalay Yilmaz, N. (2020). Detection of Coronavirus Disease 2019 Viral Material on Environmental Surfaces of an Ophthalmology Examination Room. JAMA Ophthalmology, 138(9), 990-993.

https://doi.org/10.1001/jamaophthalmo 1.2020 .3154

Bialek, S., Gierke, R., Hughes, M., McNamara, L. A., Pilishvili, T., \& Skoff, T. (2020). Coronavirus disease 2019 in children: Current status Morbidity and Mortality Weekly Report. 69(14), 422-426. https://www.cdc.gov/mmwr/volumes/6 9/wr/pdfs/mm6914e4-H.pdf

CDC. (2020). Older adults at greater risk of requiring hospitalization or dying if diagnosed ith COVID 19. https://www.cdc.gov/coronavirus/2019 -ncov/need-extra-precautions/olderadults.html

Dinas, denpasar K. (2020). Save City Kota Denpasar.

https://safecity.denpasarkota.go.id/id/c ovid19

Dinas, P. K. (2020). Peta Penyebaran $\begin{array}{llll}\text { Covid } & 19 & \text { di }\end{array}$ https://pendataan.baliprov.go.id/

Donsu, J, D, T. (2017). Psikologi Keperawatan (1st ed.). Pustaka Baru Press.

Emy, darmayanti Ni Putu; Nugrah, Arie Dharma Putra; Wisnawa, Gede Adi; Agustina, Ni Putu Dian; Diantari, N. P. A. (2020). Gambaran pengetahuan masyarakat tentang covid-19 dan perilaku masyarakat di masa pandemi covid-19. 8(3), 491-504.

Ernawati N., Rahmawati F, . (2018). Studi Korelasi Pengetahuan Ibu dalam Pencegahan TB paru Pada Anak Di Poli Anak RS TK II dr. Soepraoen. 22, 68-75.

Fiorillo, L., Cervino, G., Matarese, M., D'amico, C., Surace, G., Paduano, V., Fiorillo, M. T., Moschella, A., La Bruna, A., Romano, G. L., Laudicella, R., Baldari, S., \& Cicciù, M. (2020). COVID-19 surface persistence: A recent data summary and its importance for medical and dental settings. International Journal of Environmental Research and Public Health, 17(9). https://doi.org/10.3390/ijerph1709313 2

Hopkins University, J. (2020). COVID-19 Dashboard by the Center for Systems Science and Engineering (CSSE) at Johns Hopkins University (JHU). https://coronavirus.jhu.edu/map.html

Kemenkes. (2020a). Infeksi Emerging. https://covid19.kemkes.go.id/category/ situasi-infeksi-emerging/info-coronavirus/\#.X0O8DjURXIU

Kemenkes. (2020b). Pedoman Pencegahan dan Pengendalian Corona Virus 
Disease (Covid 19) (S. dr. Listiana Aziza, Sp.KP; Adistikah Aqmarina, SKM; Maulidiah Ihsan (ed.); Revisi ke).

KPCPEN. (2021). Peta Sebaran COVID 19. https://covid19.go.id/peta-sebaran

Li, L. quan, Huang, T., Wang, Y. qing, Wang, Z. ping, Liang, Y., Huang, T. bi, Zhang, H. yun, Sun, W., \& Wang, Y. (2020). COVID-19 patients' clinical characteristics, discharge rate, and fatality rate of meta-analysis. Journal of Medical Virology, 92(6), 577-583.

https://doi.org/10.1002/jmv.25757

Nikolai, L. A., Meyer, C. G., Kremsner, P. G., \& Velavan, T. P. (2020). Asymptomatic SARS Coronavirus 2 infection: Invisible yet invincible. International Journal of Infectious Diseases, 100, 112-116. https://doi.org/10.1016/j.ijid.2020.08.0 76

Nugroho, W. D., C, W. I., Alanish, S. T., Istiqomah, N., \& Cahyasari, I. (2020). Literature Review: Transmisi Covid19 dari Manusia ke Manusia Di Asia. Jurnal of Bionursing, 2(2), 101-112. https://doi.org/10.20884/BION.V2I2.5 1

Prihati, D. R., Wirawati, M. K., \& Supriyanti, E. (2020). Analisis Pengetahuan Dan Perilaku Masyarakat Di Kelurahan Baru Kotawaringin Barat Tentang Covid 19. Malahayati Nursing Journal, 2(4), 780-790. https://doi.org/10.33024/manuju.v2i4. 3073

Purnamasari, I. (2020). Purnamasari,I and Raharyani A,E. (2020) 'Tingkat Pengetahuan Dan Perilaku Masyarakat Kabupaten Wonosobo Tentang Covid19', Jurnal Ilmiah Kesehatan, I, pp. 33-43. Available at: https://ojs.unsiq.ac.id/index.php/jik/art icle/view/1311/783.

JurnalImiahKesehatan, Mei, 33-42. https://ojs.unsiq.ac.id/index.php/jik/art icle/view/1311/783

Putra, A. I. Y. D., Pratiwi, Made Sindy AstriYani, M. V. W., Danang, G. R., Gunawan, Ganesha, Ghaniy Muhammad Aminawati, Agnes Maria Aprilia EvelynWibhawa, I. P. G. D., Aryana, \& Suryawati, I. G. A. A. (2020). Gambaran Karakteristik Pengetahuan, Sikap dan Perilaku Risiko Covid-19 Dalam Kerangka Desa Adat di Desa Gulingan, Mengwi, Bali. Jurnal Kesehatan Andalas, 9(3), 313-319.

Satria, R. M. A., Tutupoho, R. V., \& Chalidyanto, D. (2020). Analisis Faktor Risiko Kematian Ddengan Penyakit Komorbid Covid-19. Jurnal Keperawatan Silampari, 4(1), 16891699.

Susilo, A., Rumende, C. M., Pitoyo, C. W., Santoso, W. D., Yulianti, M., Herikurniawan, H., Sinto, R., Singh, G., Nainggolan, L., Nelwan, E. J., Chen, L. K., Widhani, A., Wijaya, E., Wicaksana, B., Maksum, M., Annisa, F., Jasirwan, C. O. M., \& Yunihastuti, E. (2020). Coronavirus Disease 2019: Tinjauan Literatur Terkini. Jurnal Penyakit Dalam Indonesia, 7(1), 45. https://doi.org/10.7454/jpdi.v7i1.415

Utami, R. A., Mose, R. E., \& Martini, M. (2020). Pengetahuan, Sikap dan Keterampilan Masyarakat dalam Pencegahan COVID-19 di DKI Jakarta. Jurnal Kesehatan Holistic, 4(2), 68-77. https://doi.org/10.33377/jkh.v4i2.85

Wawan A. dan M. Dewi. (2019). Teori \& Pengukuran Pengetahuan, Sikap Dan Perilaku Manusia (B. Jhon (ed.); Cetakan II). Nuha Medika.

World Health Organization. (2020a). Anjuran mengenai penggunaan masker dalam konteks COVID-19. World Health Organization, April, 1-6.

World Health Organization. (2020b). Transmisi SARS-CoV-2: implikasi terhadap kewaspadaan pencegahan 
infeksi. Pernyataan Keilmuan, 1-10. who.int

World Health Organization, W. (2020c). Anjuran mengenai penggunaan masker dalam konteks COVID-19. World Health Organization, April, 1-17. https://www.who.int/docs/defaultsource/searo/indonesia/covid19/anjura n-mengenai-penggunaan-maskerdalam-konteks-covid-19-june20.pdf?sfvrsn=d1327a85_2 